Redactor

Bojana Obradović, Ph. D.

\title{
Cell and Tissue Engineering
}

ind Springer 


\section{CONTENTS}

1. CREATION OF LIVING TISSUE: AN ENGINEERING FEAT ......................... 1

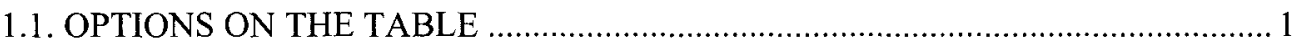

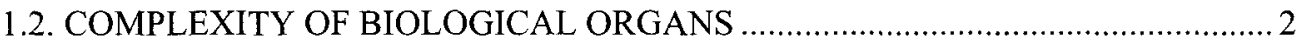

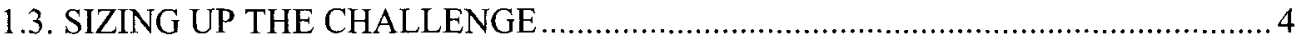

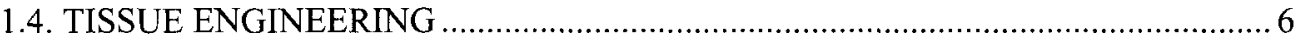

2. CLASSICAL AND QUANTUM INFORMATION PROCESSING

IN DNA-PROTEIN CODING........................................................................... 9

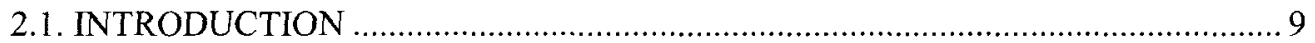

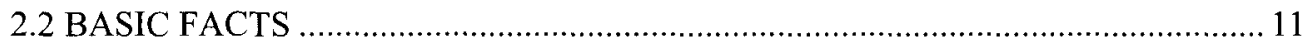

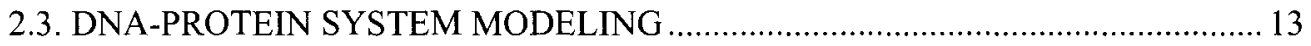

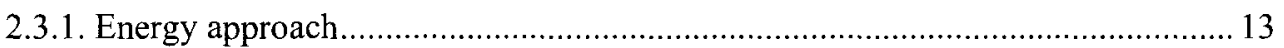

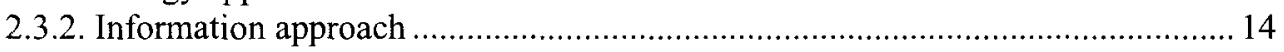

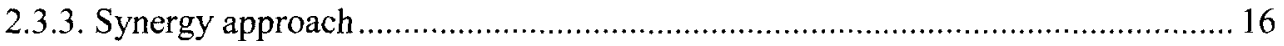

2.4 HOW DOES THE DNA-PROTEIN INFORMATION SYSTEM WORK? .............. 17

2.4.1. New considerations in mechanisms of DNA action .......................................... 17

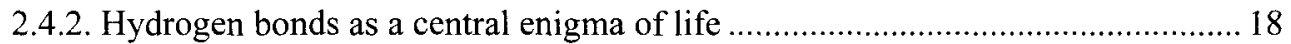

2.4.3. Synergy of classical and quantum information .............................................. 19

2.4.4. Violation of the synergetic DNA-protein information channel and cancer .......... 21

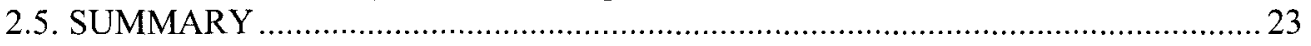

3. UNRAVELING THE MEMBRANE FUSION IN SECRETORY CELLS AT THE NM-LEVEL: A NANOBIOENGINEERING APPROACH.................................... 27

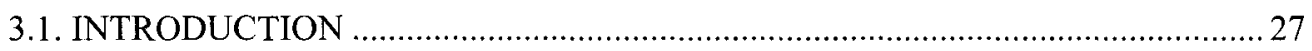

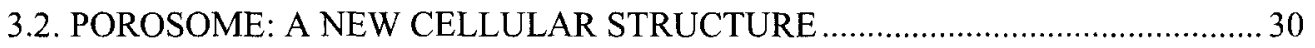

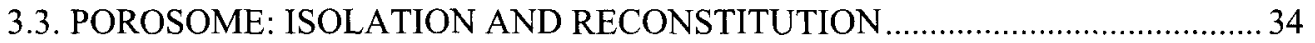

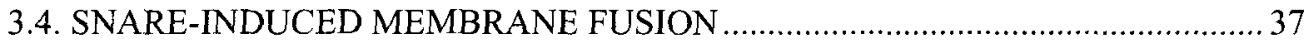

3.5. REGULATION OF SECRETORY VESICLE SWELLING: INVOLVEMENT IN

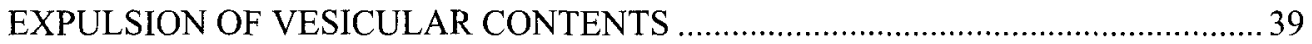

3.6. MOLECULAR UNDERSTANDING OF CELL SECRETION ........................... 40

4. BIOPHYSICAL AND BIOCHEMICAL DETERMINANTS OF CONTRACTILE FORCE GENERATION, REGULATION, AND FUNCTION.................................. 44

4.1. THE FUNDAMENTAL PROBLEM OF MUSCLE CONTRACTION ................... 44

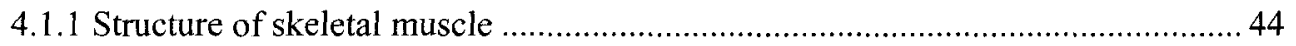

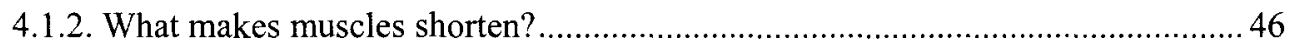

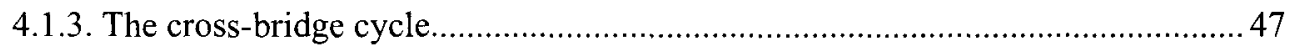

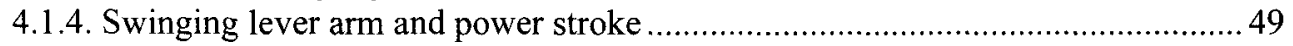

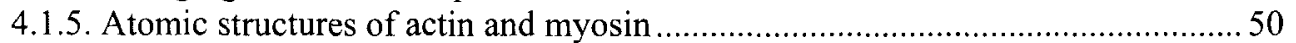

4.2. BUILDING A COMPREHENSIVE MODEL OF MUSCLE CONTRACTION ...... 51

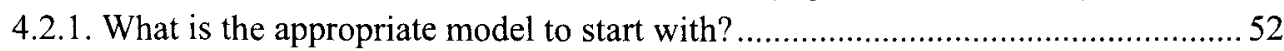

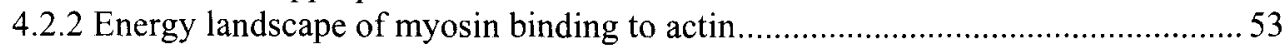

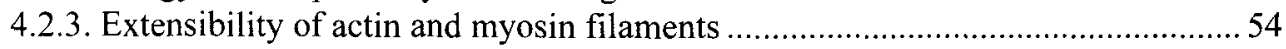

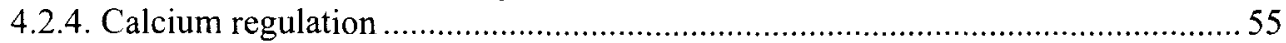

4.3 MATHEMATICAL FOUNDATIONS OF SLIDING FILA-MENT THEORY AND COMPUTATIONAL METHODS THEORETICAL MODELS OF MUSCLE

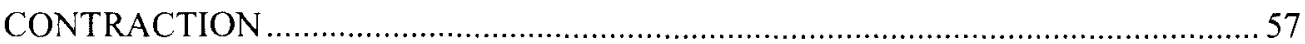

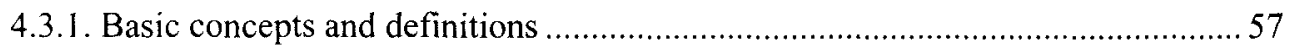


4.3.2. A probabilistic formulation of cross-bridge kinetics ......................................58

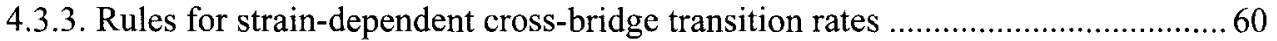

4.3.4. Stochastic strain dependent binding in 3D sarcomere lattice ..............................62 62

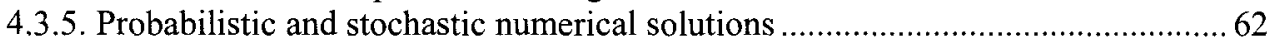

4.4. THEORETICAL MODELS OF MUSCLE CONTRACTION ................................6 63

4.4.1 Huxley's sliding filament model in extensible filament lattice ............................63

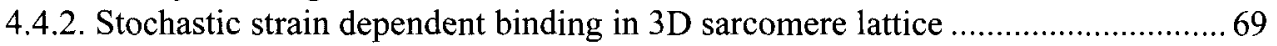

4.4.3. Thin filament regulation in skeletal muscle ............................................... 72

4.4.4. The latch regulatory scheme in smooth muscle............................................... 79

5. CYTOSKELETAL PRESTRESS AS A DETERMINANT OF DEFORMABILITY AND RHEOLOGY OF ADHERENT CELLS ......................... 92

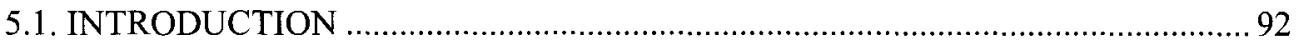

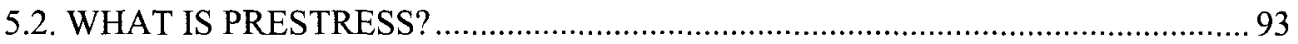

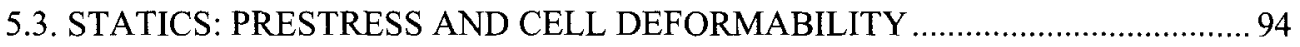

5.3.1. Measurements of cytoskeletal prestress and stiffness .................................... 96

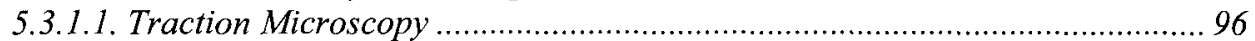

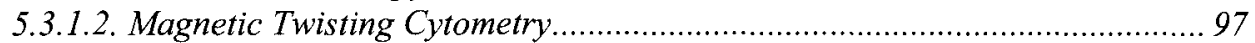

5.3.2. Modeling of the steady-state mechanical behavior of the CSK .......................... 98

5.3.2.2. Prestress induced stiffness of the CSK.............................................. 101

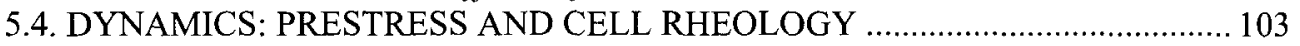

5.4.1. Mechanisms that link cytoskeletal prestress to rheology ................................ 106

5.4.1.1. Tensegrity and cytoskeletal rheology .................................................. 106

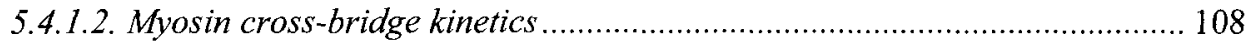

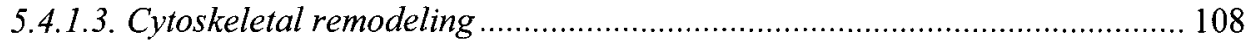

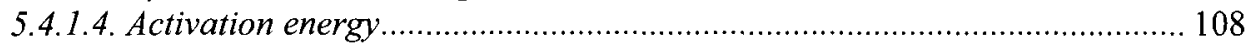

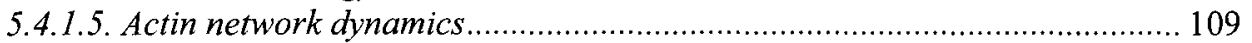

5.4.1.6. Dynamics of individual polymer chains under sustained tension................. 110

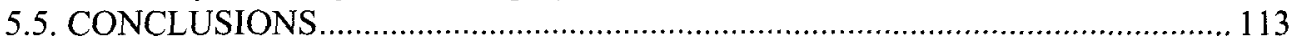

6. CELL AND TISSUE ORGANIZATION IN SOFT MATERIALS: INSIGHT FROM MATHEMATICAL AND BIOPHYSICAL MODELLING ........................ 119

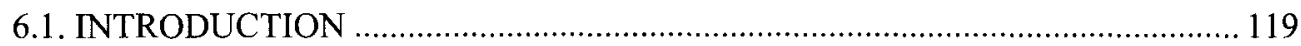

6.1.1. Overview of cell and tissue organization principles for adherent cells ............. 119

6.1.2. Classification of mechanical signals and biological responses ...................... 120

6.1.3. Effect of substrate mechanics on cell behavior ...................................... 121

6.1.4. Sensing substrate mechanics: Active mechanosensing ............................... 121

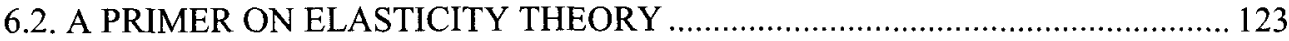

6.3. TOWARDS A SYSTEM UNDERSTANDING OF THE INFLUENCE OF

SUBSTRATE MECHANICS ON CELL AND TISSUE ORGANIZATION …............ 125

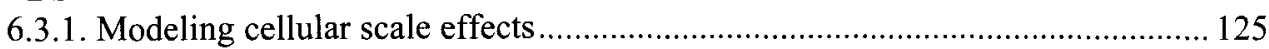

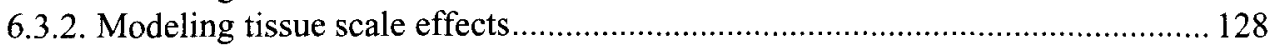

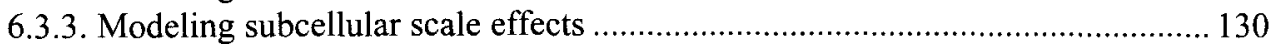

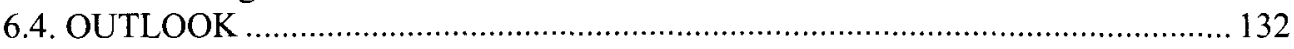

7. SUBSTRATE STRETCHING AND ORIENTATION OF ACTIVE CELLS AS A

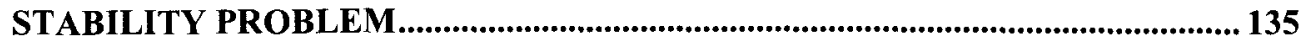

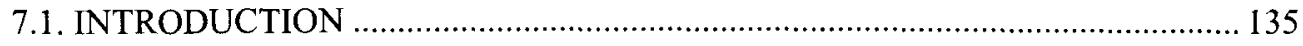

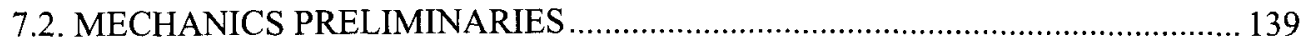

7.3. THE NONLINEAR HOMOGENEOUS STRAIN FIELD

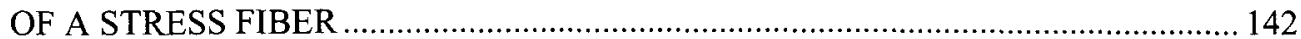

7.4. THE EQUILIBRIUM PLACEMENTS OF THE STRESS-FIBERS ...................... 145

7.5. GLOBALLY STABLE EQUILIBRIUM PLACEMENTS ................................... 148 


\section{ROLES OF MECHANICAL FORCES AND EXTRACELLULAR MATRIX} PROPERTIES IN CELLULAR SIGNALING IN THE LUNG

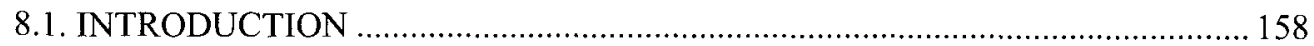

8.2. MAIN CONSTITUENTS OF THE LUNG CONNECTIVE TISSUE .................... 160

8.2.1. Properties of collagens ............................................................................... 160

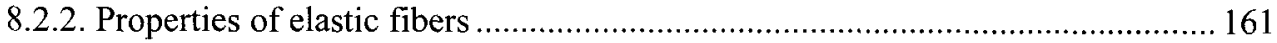

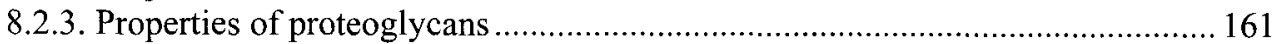

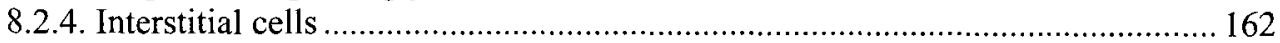

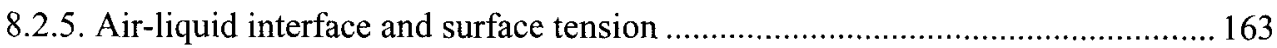

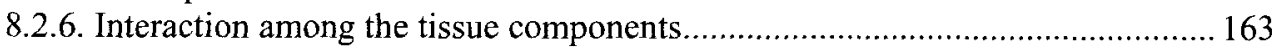

8.3. MECHANICAL PROPERTIES OF THE NORMAL LUNG .............................. 164

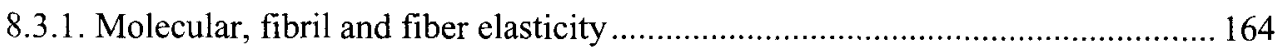

8.3.2. Elasticity of lung collagen, alveolar wall, tissue strip and whole lung............... 166

8.4. EFFECTS OF MECHANICAL FORCES ON THE LUNG PARENCHYMA ....... 168

8.4.1. Mechanical forces, cell signaling and biomechanical properties of the ECM.... 168

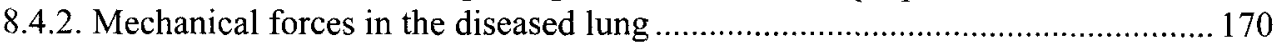

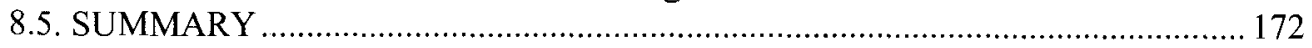

9. ENZYME SIGNALING: IMPLICATIONS FOR TISSUE ENGINEERING..... 179

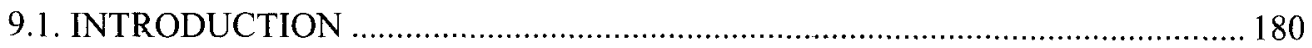

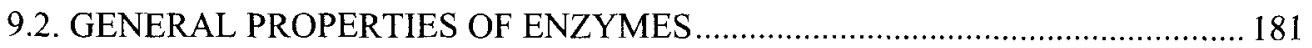

9.3. METALLOPROTEINASES IN SIGNALING .............................................. 183

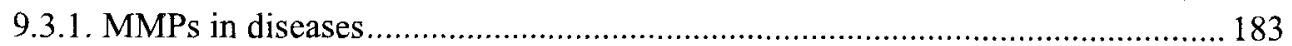

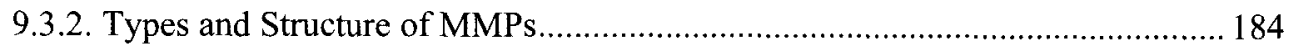

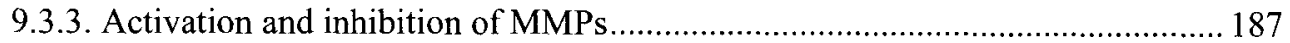

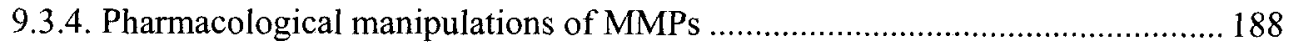

9.4. GENERAL CONSIDERATIONS FOR TISSUE ENGINEERING ..................... 190

10. HYDROGELS IN TISSUE ENGINEERING .................................................... 197

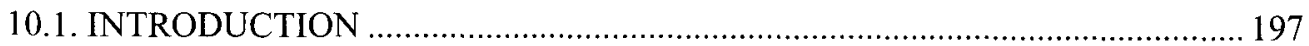

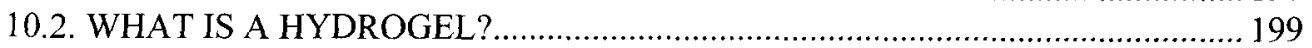

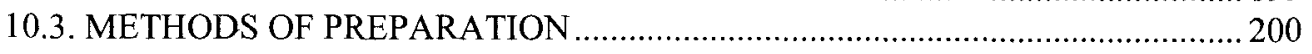

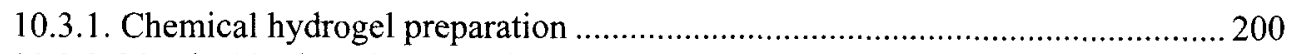

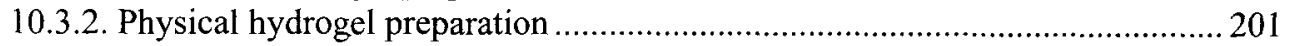

10.3.2.1. Hydrogels obtained by ionic interactions ............................................ 202

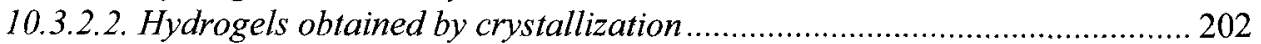

10.3.2.3. Hydrogels obtained from amphiphilic block and graft co-polymers .......... 203

10.3.2.4. Hydrogels obtained by hydrogen bond interactions ................................. 204

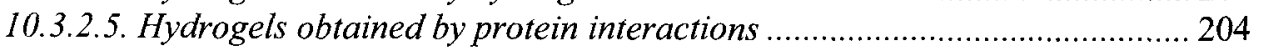

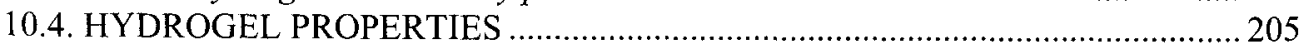

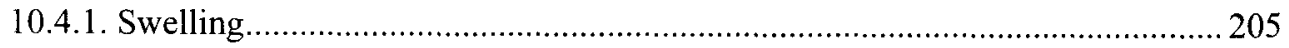

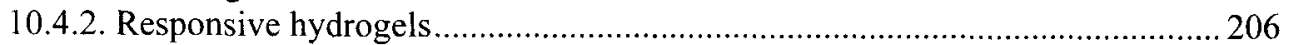

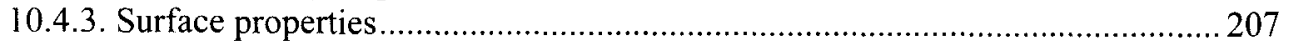

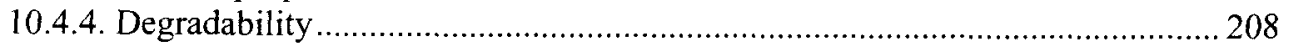

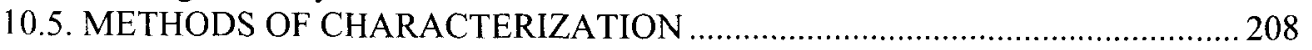

10.6. BIOMEDICAL / TISSUE ENGINEERING APPLICATIONS ........................... 209

11. BIOREACTORS IN TISSUE ENGINEERING ............................................... 217

11.1. INTRODUCTION: WHAT ARE TISSUE-ENGINEERING BIOREACTORS?.. 217

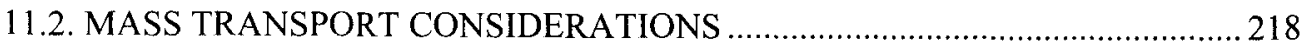




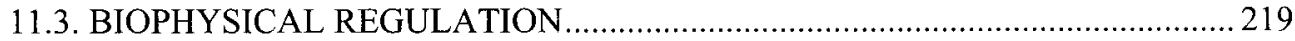

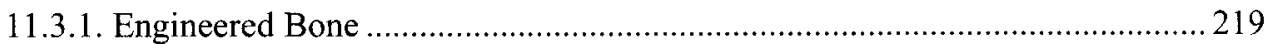

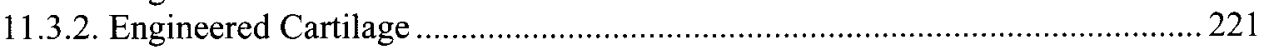

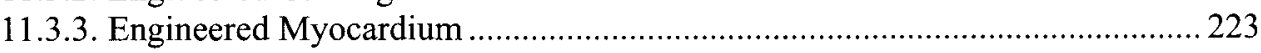

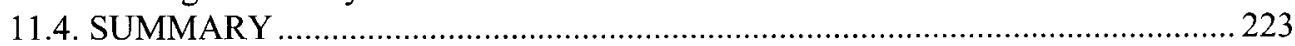

12. APPROACHES TO MATHEMATICAL MODELING OF TISSUE

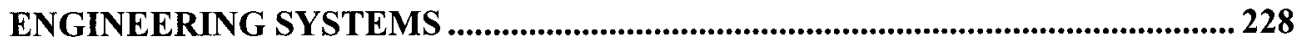

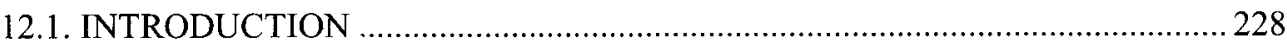

12.2. CHARACTERIZATION OF IN VITRO CULTIVATING CONDITIONS ......... 231

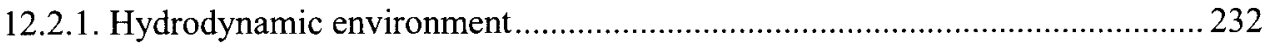

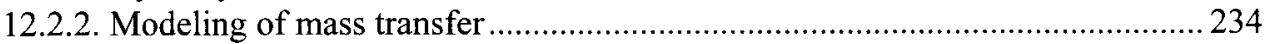

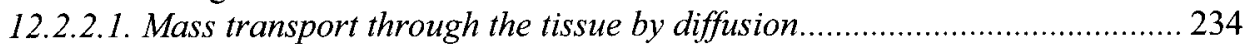

12.2.2.2. Enhancement of mass transport through the tissue by convection ............. 239

12.3. CORRELATIONS OF CULTIVATING CONDITIONS WITH THE CELL

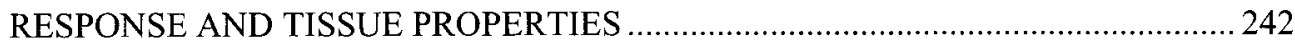

12.3.1. Correlations of hydrodynamic conditions with the tissue growth ....................242

12.3.2. Mathematical model of GAG accumulation in engineered cartilage constructs 244

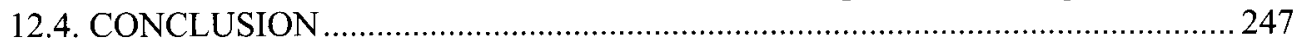

13. COMPUTATIONAL MODELING OF TISSUE SELF-ASSEMBLY ....................251

13.1. THE MODELING APPROACH TO MORPHOGENESIS ................................251

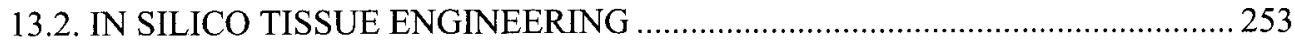

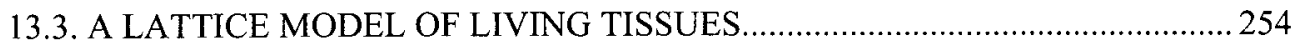

13.4. MONTE CARLO SIMULATIONS OF THE SELF

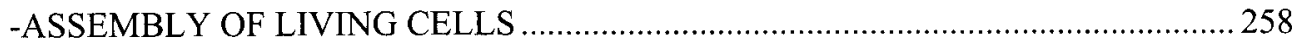

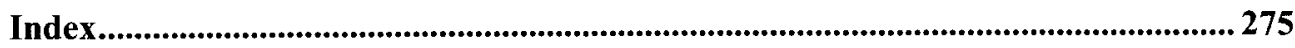

